\title{
Biochemical profile of 'Niagara Rosada' grapes under different rootstocks and training system
}

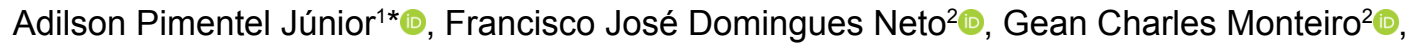 \\ Cristine Vanz Borges ${ }^{2} \odot$, Giuseppina Pace Pereira Lima² ${ }^{\oplus}$, Marco Antonio Tecchioº \\ ${ }^{1}$ Centro Universitário das Faculdades Integradas de Ourinhos, Ourinhos, SP, Brasil. E-mail: adilson_pimentel@outlook.com \\ ${ }^{2}$ Universidade Estadual Paulista Júlio de Mesquita Filho, Câmpus de Botucatu, Faculdade de Ciências Agronômicas, Botucatu, SP, Brasil. E-mail: fjdominguesneto@hotmail.com; \\ gean.monteiro@yahoo.com.br; cristine.vanzb@gmail.com; finalima@gmail.com; marco.a.tecchio@unesp.br
}

ABSTRACT: Grapevines are used to be trained to different systems, while there is a paucity of literature on the main cordon disposition with regards to grape quality, especially grafted on to different rootstocks. Therefore, a field experiment took place in the city of São Manuel, state of São Paulo, Brazil. This study aimed to evaluate the quality of the 'Niagara Rosada' grapes by training them to vertical shoot position (VSP) system with unilateral and bilateral cordons grafted on to rootstocks during two crop seasons (2015 and 2016). To assess the data, a 22 factorial setup organized in a randomized complete block design was used, corresponding to two rootstocks ('IAC 766 Campinas' and 'IAC 572 Jales') and two cordons (unilateral and bilateral cordon). The variables assessed were the content of soluble solids, titratable acidity, fruit-ripeness index, reducing sugars, total phenolic compounds, total flavonoids, anthocyanins, antioxidant activity via DPPH and FRAP. Results indicated that 'IAC 766 Campinas' rootstock and bilateral cordon improved the chemical quality in grapes, especially the contents of anthocyanins and sugars. This management practice should be selected when growing 'Niágara Rosada' grapes, provided that there is an influence in the quality of the final product.

\section{Perfil bioquímico da uva 'Niagara Rosada' sob diferentes portaenxertos e sistemas de condução}

RESUMO: As videiras são plantas altamente responsivas aos diferentes manejos adotados, porém, são escassos os estudos que indiquem os impactos da disposição do cordão principal em sistemas de condução associados a diferentes portaenxertos na qualidade das uvas. O presente trabalho foi desenvolvido em São Manuel, São Paulo, Brasil e objetivou avaliar a influência do tipo de cordão esporonado e porta enxertos na qualidade da uva 'Niagara Rosada' durante dois ciclos de produção. 0 delineamento experimental foi em blocos casualizados em esquema fatorial $2 \times 2$, correspondendo aos dois portaenxertos, sendo o 'IAC 766 Campinas' e o 'IAC 572 Jales' e dois sistemas de condução do cordão principal, cordão unilateral e cordão bilateral. As variáveis estudadas foram: o teor de sólidos solúveis, acidez titulável, índice de maturação, açúcares redutores, compostos fenólicos totais, flavonoides totais, antocianinas e atividade antioxidante via DPPH e FRAP. O portaenxerto 'IAC 766 Campinas' e cordão bilateral promoveram melhoria da qualidade química das uvas, principalmente no teor de antocianinas e açucares. Este manejo deve ser o preferido para a produção de uvas 'Niágara Rosada', pois influencia na qualidade do produto final.

Palavras-chave: compostos bioativos; cordão esporonado; qualidade; Vitis labrusca; videira

\footnotetext{
*Adilson Pimentel Júnior - E-mail: adilson_pimentel@outlook.com (Corresponding author)

Associate Editor: Sergio Ruffo Roberto
} 


\section{Introduction}

In 2018, Brazil produced about 1.591 million tons of grapes, which $51 \%$ was destined to beverages industry and $49 \%$ to table consumption. Besides that, 'Niagara Rosada' grapes has been accounted for $60 \%$ table consumption (Carvalho et al., 2020). Brazil and other tropical countries have already researched the rootstocks and scion relation with regards to grape yields and post-harvest quality, which is mainly related to antioxidant compounds (Borges et al., 2013).

The quality of the grape is somehow related to the edaphoclimatic conditions, scion/rootstock compatibility (Silva et al., 2019) and training system. Furthermore, scion and rootstock have already been known to alter microclimate; thus, impacting on the yields and quality of the fruits (Liu et al., 2018). Also, the balance between vegetative and reproductive activity interferes in the bioactive compound concentrations, such as (poly)phenols in the final quality of grapes and their derivatives (Borges et al., 2013).

In grapes, phenolic compounds are widely studied as they present many health benefits, such as antioxidant and anti-inflammatory activity (Colombo et al., 2019). These compounds are found in different parts of the grape berries, but the rind contains the highest amount of these metabolites, that is, anthocyanins that plays a very important role regarding to red colour, besides affecting the quality of the final product. Vitis vinifera ('Cabernet Sauvignon' and 'Shiraz'), Vitis labrusca ('Bordô') and hybrids ('Niagara Rosada') have already been evaluated in rootstocks that were conferred with high vigor. Therefore, studies have shown that 'IAC 313 Tropical' rootstock tended to improve the concentration of anthocyanins and (poly)phenols in fruits when compared to 'IAC 572 Jales' (Mota et al., 2009).

Agronomic Institute of Campinas (IAC) has developed some rootstocks that are being used in Brazil for viticulture, such as 'IAC 766 Campinas' (middle-vigor) and 'IAC 572 Jales' (high-vigor), due to their vigor, potential adaptability to different soil environments and scion/rootstock compatibility; especially for 'Niagara Rosada' that is well-adapted and widely grown hybrid in Brazil (Tecchio et al., 2014). Initially, some studies reported that 'Niagara Rosada' grapes grafted on to 'IAC 766' showed higher $\mathrm{pH}$, soluble solids and acidity when compared to grapevines grafted on to 'IAC 572' (Mota et al., 2009). Nevertheless, Silva et al. (2019) found significant differences in basic quality attributes (i.e. $\mathrm{pH}$, acidity and fruit-ripeness index) and antioxidants (anthocyanins, transresveratrol and phenolic acids) in hybrids ('BRS Carmem', 'BRS Cora' and 'IAC 138-22 Maximo') grafted on to different rootstocks, but the variation in these attribute concentrations also depends on the cultivar. The interaction between scion/ rootstock and training system can affect the vigor of plants that will later reflect on the grape berry quality; consequently, leading to different bioactive compound profiles in fruits and derivatives (Borges et al., 2013; Silva et al., 2019).

Growers are used to train vines to unilateral or bilateral cordons (Tecchio et al., 2014), since the horizontal cordon reduces the apical dominance in grapevines, as a consequence developing a better scion division and then, avoiding infertile and vegetative buds. However, there are few studies on vertical shoot position (VSP) system with unilateral and bilateral cordons to assess the quality of the grapes, especially grafted on to different rootstocks. This study aimed to evaluate the quality of the 'Niagara Rosada' grapes grafted on to rootstocks and trained to unilateral and bilateral cordon systems during two crop cycles (2015 and 2016).

\section{Materials and Methods}

\section{Experiment characterization and implantation}

A field experiment was conducted during two crop cycles (2015 and 2016) at the Experimental Farm of School of Agriculture (FCA UNESP), which is located in the city of São Manuel, SP $\left(22^{\circ} 44^{\prime} \mathrm{S}\right.$ and $48^{\circ} 34^{\prime} \mathrm{O}$, at an altitude of $740 \mathrm{~m}$ above sea level). According to the Köppen classification, the climate of the area is the Cfa type, that is, a hot temperate climate (mesothermic), with concentrated rains from November to April (summer) and an average annual rainfall of $1,465 \mathrm{~mm}$; the mean temperature of the coldest and hottest month do not exceed 14.5 and $27.1^{\circ} \mathrm{C}$. The soil of the experimental area is classified as dystrophic Red Yellow Latosol.

The 'Niagara Rosada' grape (Vitis labrusca $\times$ Vitis vinifera) was selected for this study over two agricultural years. They were planted at $2 \mathrm{~m}$ spacing between rows and $0.8 \mathrm{~m}$ between plants, i.e., 6,250 vines ha-1). Moreover, vertical shoot position (VSP) system was used with three wire cordons at 1.0, 1.3 and $1.6 \mathrm{~m}$ above the ground. When the colour of the grape berries started to change, plants were protected with antihail screens. Also, spur pruning was done during late winter (August), when a single bud retained per spur. Immediately after pruning, $5 \%$ hydrogen cyanamide (Dormex ${ }^{\circledR}$ ) was applied to promote uniformity of bud sprouting. After sprouting, 10 productive branches per vine were maintained, in which grape blossom branches were removed; then, they were fixed to wire cordons, besides the removal of axillary branches and leaves below the bunches (defoliation). Tipping was performed on the third leaf above the last wire cordon. The application of fungicide was proceeded because of the rain conditions and disease incidence by spraying. Grapevine fertilizations followed the recommendations based on Raij et al. (1997). Furthermore, the drip irrigation system was activated to keep the soil in the field capacity when necessary.

\section{Experimental design, treatments, and harvest period}

To assess the data, a $2 \times 2$ factorial setup organized in a randomized complete block design was used; corresponding to two rootstocks: 'IAC 766 Campinas' $[V$. riparia $\times\{\mathrm{V}$. cordifolia $\times V$. rupestres $\} \times$ Vitis caribaea], and 'IAC 572 Jales' [\{V. riparia $x V$. rupestris $\mathrm{x} V$. caribaea]; and two main cordons (unilateral and bilateral) (Figure 1). Therefore, four treatments consisted of the combination between rootstocks and training systems with six blocks and 24 plots, that is, five vines per plot. 

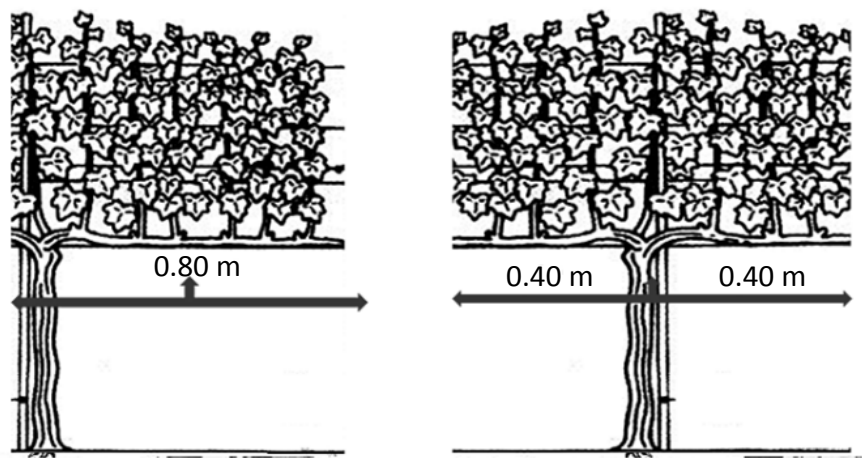

Source: Pimentel Júnior (2020)

Figure 1. Grapevine trained on unilateral (left) and bilateral (direct) cordons.

Harvesting was performed when soluble solids (SS) content in grape berries was above $14^{\circ} \mathrm{Brix}, \mathrm{pH}$ above 3.5 and an intense and uniform pink colour. In each plot, ten representative grape bunches of each treatment were collected for the physicochemical characterization of the fruits.

\section{Physicochemical analysis of grapes}

The physicochemical composition was determined in grape must by direct pressing in a sample composed of 100 grape berries per experimental plot. Soluble solids content (SS) was determined using a portable digital refractometer (Atago ${ }^{\circledR}$ ) and results were expressed in ${ }^{\circ} \mathrm{Brix}$. Titratable acidity (TA) was determined by potentiometric volume, titrating sodium hydroxide solution $\left(0.1 \mathrm{~mol} \mathrm{~L}^{-1}\right)$, results were then expressed in $\mathrm{g}$ of tartaric acid $100 \mathrm{~g}^{-1}$ of pulp. The fruit-ripeness index was obtained by the ratio between SS and TA. The content of reducing sugars was evaluated through the colorimetric method on an analytical glucose curve $(510 \mathrm{~nm})$ that was proposed by Somogyi-Nelson (Nelson, 1944), results were therefore expressed as a percentage (\%).

\section{Biochemical analysis of grapes}

\section{Obtaining grape extract}

Initially, $100 \mathrm{~g}$ of grapes had their seeds removed from each repetition. Afterwards, both pulp and skin were immediately sprayed with liquid nitrogen and homogenized in acidified methanol that was prepared using $\mathrm{HCl} /$ methanol/ water mixture, 1:70:20, v/v. After stirring for $1 \mathrm{~min}$, samples were kept in a dark condition for two hours at $8^{\circ} \mathrm{C}$ and centrifuged at $6,000 \mathrm{~g}$ for $7 \mathrm{~min}$ at $5{ }^{\circ} \mathrm{C}$. The precipitate was resuspended, and the extraction was repeated twice. At the end, supernatants were mixed, and analyses were performed in triplicate.

\section{Total phenolic compounds, total flavonoids and anthocyanins}

Total phenolic compounds in grapes was determined through Folin-Ciocalteau reagent (Singleton \& Rossi Jr, 1965), results were then expressed in mg equivalent of gallic acid 100 $\mathrm{g}^{-1}$ fresh weight. The content of total flavonoids was obtained according to the spectrophotometric method (Popova et al., 2004), and results were expressed in mg equivalent of quercetin $100 \mathrm{~g}^{-1}$ of the grape berry. The total content of monomeric anthocyanins was determined by the differential $\mathrm{pH}$ method (Lee et al., 2005). Buffer solutions of $25 \mathrm{mM} \mathrm{KCl} \mathrm{pH}$ 1.0 and $0.4 \mathrm{M} \mathrm{CH} 3 \mathrm{COONa}, \mathrm{pH} 4.5$ were used at absorbances measured at 520 and $700 \mathrm{~nm}$ in a spectrophotometer (Instrutherm ${ }^{\circledR}$ UV-Vis UV 2000ㄹ). The content of monomeric anthocyanins was therefore expressed as cyanidin-3-glycoside equivalents in $\mathrm{mg}$ per $100 \mathrm{~g}^{-1}$ of grape.

\section{Antioxidant capacity (DPPH and FRAP)}

The antioxidant activity in vitro was determined through DPPH and FRAP. The colorimetric method of DPPH is based on the free radicals scavenging activity of DPPH-2,2-diphenyl-1picrilhidrazil (Kim et al., 2002), results were expressed in $\mathrm{mg}$ equivalent Trolox $\mathrm{g}^{-1}$. Antioxidant activity was assessed through FRAP, that is, followed the method described by Benzie and Strain (Benzie \& Strain, 1996), results were expressed in $\mu \mathrm{mol}$ $\mathrm{Fe}^{+} 100 \mathrm{~g}^{-1}$.

\section{Statistical analysis}

Data were subjected to analysis of variance ( $F$ test) and compared by the Tukey test at $5 \%$ probability by using the SISVAR computer program (Lavras, Brazil) (Ferreira, 2011). The averages were then submitted to multivariate statistical analysis (Principal Component Analysis, PCA) through XLSTAT statistical software - version 2017 (Addinsoft, France).

\section{Results and Discussion}

\section{Physicochemical analysis}

There were no significant differences for acidity and fruit-ripeness index (Table 1). However, soluble solids and sugar contents showed significant differences with regards to rootstock and training system. The lowest SS content $\left(15.47^{\circ} \mathrm{Brix}\right)$ was observed in 'Niagara Rosada' grapes trained to bilateral cordon and grafted on to 'IAC 572' rootstock. Some studies have already demonstrated higher levels for SS and TA in 'Niagara Rosada' grafted on to 'IAC 766', when compared to 'IAC' 572' (Mota et al., 2009). Those traits are highly influenced by weather conditions and soil attributes (Gutiérrez-Gamboa et al., 2018). Furthermore, this current study indicated potential harvest with a well-balanced fruit ripeness and acidity in 'Niagara Rosada' grape must, regardless of the management practice. But the unilateral cordon provided the highest sugar content when grapes were grafted on to both rootstocks (Table 1), especially 'IAC 766' (17.16\%). Previous studies also presented high sugar content (glucose and fructose) in hybrids, such as 'Isabel Precoce', 'BRS Cora' and 'IAC 138-22 Maximo' grafted on to 'IAC 766' rootstock (Silva et al., 2019). These outcomes are related to distinct rootstock conferred vigor, that is, there is a difference in their needs related to water and nutrient uptake (Tecchio et al., 2014), which can affect grape yields and quality.

\section{Biochemical compounds analysis}

Results showed that the means of phenolic compounds were affected by rootstocks and training systems (Table 2 ). 
Table 1. Physicochemical variables of 'Niagara Rosada' grapes grafted on to different rootstocks and training systems over two productive cycles (2015 and 2016).

\begin{tabular}{|c|c|c|c|c|c|}
\hline Rootstock & Training system & $\begin{array}{c}\text { Soluble solids } \\
\text { ( }{ }^{\circ} \text { Brix) }\end{array}$ & $\begin{array}{c}\text { Acidity } \\
\left({\left.\mathrm{g} 100 \mathrm{~g}^{-1}\right)}\right.\end{array}$ & $\begin{array}{c}\text { Fruit-ripeness } \\
\text { index } \\
\end{array}$ & $\begin{array}{c}\text { Sugar } \\
(\%) \\
\end{array}$ \\
\hline \multirow{2}{*}{ 'IAC 766’ } & Unilateral & $15.73 \mathrm{aA}$ & $0.51 \mathrm{aA}$ & $31.26 \mathrm{aA}$ & $17.16 \mathrm{aA}$ \\
\hline & Bilateral & $16.07 \mathrm{aA}$ & $0.56 \mathrm{aA}$ & $32.27 \mathrm{aA}$ & $14.31 \mathrm{bB}$ \\
\hline \multirow{2}{*}{ 'IAC 572’ } & Unilateral & $15.97 \mathrm{aA}$ & $0.50 \mathrm{aA}$ & $33.01 \mathrm{aA}$ & $16.42 \mathrm{aA}$ \\
\hline & Bilateral & $14.47 \mathrm{bB}$ & $0.58 \mathrm{aA}$ & $32.31 \mathrm{aA}$ & $15.87 \mathrm{bA}$ \\
\hline
\end{tabular}

Means followed by the same lowercase letter (training system) and uppercase letter (rootstock) in the column indicate that the results do not differ by Tukey test ( $\mathrm{x} \geq 0.05$ ).

Table 2. Bioactive compounds of 'Niagara Rosada' grapes grafted on to different rootstocks and training systems over two productive cycles (2015 and 2016).

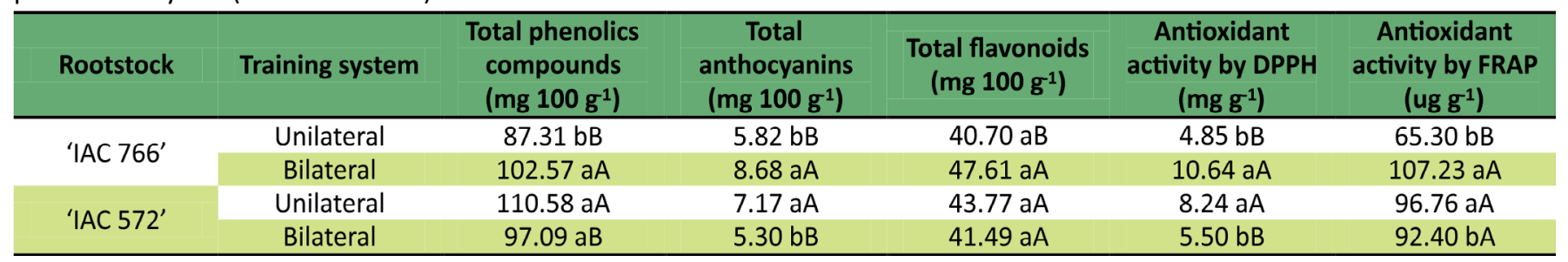

Means followed by the same lowercase letter (training system) and uppercase letter (rootstock) in the column indicate that the results do not differ by Tukey test ( $\mathrm{p} \geq 0.05$ ).

For 'Niagara Rosada' grafted on to 'IAC 766' and trained to a bilateral cordon system, results showed high levels of

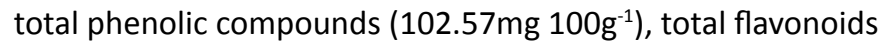

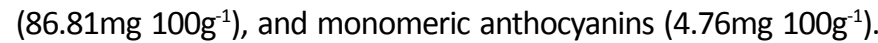
These compounds influenced antioxidant activity that was measured by DPPH and FRAP. Despite total flavonoids, high levels of these compounds, such as total phenolic compounds

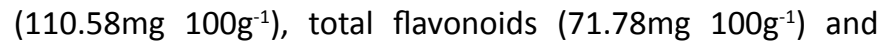

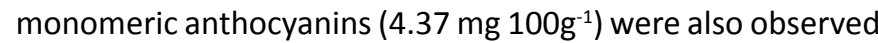
in 'Niagara Rosada' grafted on to 'IAC 572' rootstock trained to a unilateral cordon system (Table 2).

The impact of training systems on grapevine has been extensively studied in literature. Therefore, this study shows some of these influences on physicochemical traits in grapes and by-products, which were also associated with different rootstock, since the microclimate suffers changes with regards to the metabolites distribution and synthesis by the amount of radiation and intercepted nutrients that alters yield and fruit quality (Liu et al., 2018; Sabbatini et al., 2015).

Furthermore, some studies has already stated that 'IAC 766' rootstock improved compounds accumulation with important biological properties such as anthocyanins and trans-resveratrol ('IAC 138-22 Maximo') and phenolic acids ('Isabel Precoce'), when compared to 'IAC 572' (Silva et al., 2019). According to these authors, the rootstock significantly affects the qualitative aspects of the grape. The balance between vegetative and reproductive activity interferes with the final concentration of (poly)phenols (Borges et al., 2013). Moreover, Vitis vinifera ('Cabernet Sauvignon' and 'Shiraz'), Vitis labrusca ('Bordô') and hybrids ('Niagara Rosada') have already demonstrated that rootstocks conferred with less vigor induced great accumulation of anthocyanins and (poly) phenols in fruits (Mota et al., 2009; Ozden et al., 2010). Besides that, rootstock conferred with high vigor can provide an overproduction of nitrogenous substances in the sap of the vine, which negatively affects grape colour and by-products (wine and juice) (Borges et al., 2013).
Results positively demonstrated a significant correlation between total flavonoids and anthocyanins in 'Niagara Rosada' ( $p<0.05$ ) with the antioxidant activity of the analysed fruits (DPPH: 0.99 and 0.97; FRAP: 0.70 and 0.82, respectively). Phenolic compounds have important biological properties and are primarily responsible for beneficial health effects, especially flavonoids (anthocyanins) (Borges et al., 2013; Silva et al., 2017). The secondary metabolites are found in different parts of the grape berries, but mostly in the red grape skin, which also varies according to the cultivar (Silva et al., 2019), crop area (Gutiérrez-Gamboa et al., 2018) and management practices, such as the type of pruning (Liu et al., 2018). However, the scion and rootstock interaction has strongly influenced on the antioxidant activity in grape juices, such relation was even greater than the isolated effect of grafting (Silva et al., 2019). According to Silva et al. (2019), the rootstock highly influences on antioxidant capacity of grapes and by-products from Brazilian hybrids, but it also depends on the choosing the right scion according to the productive system (Silva et al., 2019). After all, outcomes demonstrated that studies with different rootstock/scion and different training systems are becoming extremely important to maximize yield and increase the quality of fruits.

\section{Principal component analysis (ACP)}

The Principal Component Analysis (PCA) was chosen to establish a descriptive model for grouping the data set of 'Niagara Rosada' grafted on to different rootstocks and trained to two different systems. The PCA explained $94.22 \%$ of the data variation (PC1 + PC2) (Figure 2). PC1 score explained $70.21 \%$ of the data variation; and was responsible for separating the best outcome treatments. The 'IAC 572' rootstock trained to unilateral cordon system and the 'IAC 766' rootstock trained to bilateral cordon system stood out in most chemical attributes; therefore, grouped in PC1+. PC2 
explained $24.01 \%$ of the data variation; and was responsible for separating the best treatments towards the analysed variables. The 'IAC 572' rootstock trained to unilateral cordon system showed the highest levels of total phenolic compound, sugars and fruit-ripeness index; thus, grouping into $\mathrm{PC2}+$. On the contrary, 'Niagara Rosada' grafted on to 'IAC 766' and trained to bilateral cordon system showed the highest levels of total flavonoids, monomeric anthocyanins and antioxidant capacity, regardless of the analytical method used (DPPH and FRAP); thus, grouping into PC2-. Moreover, the 'IAC 572' trained to bilateral cordon system showed greater acidity, as well as 'IAC 766' trained to unilateral cordon system, which showed the poorest outcomes for most of all analysed chemical compounds; thus, grouping into PC1.

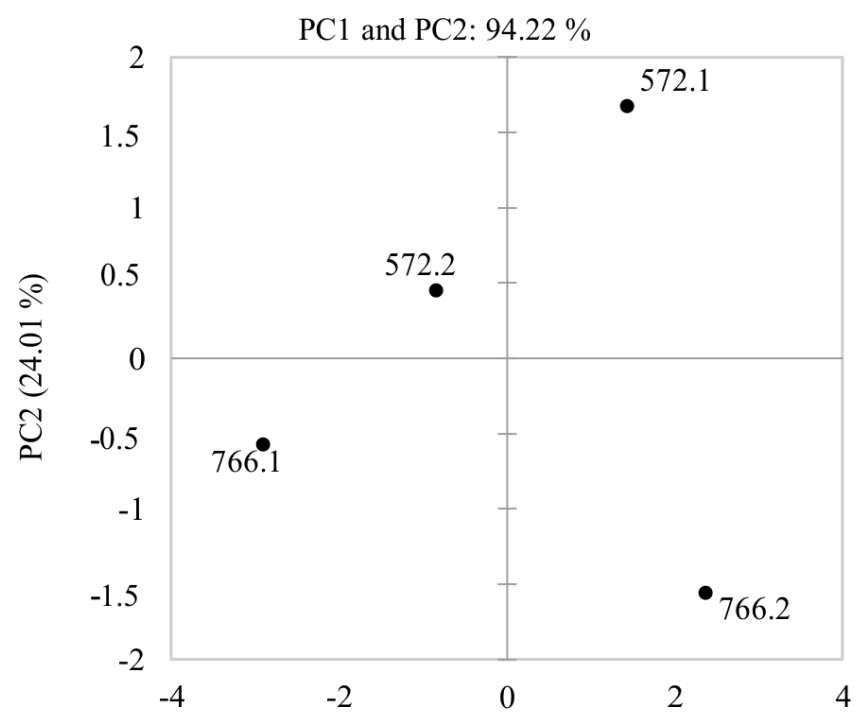

PC1 $(70.21 \%)$

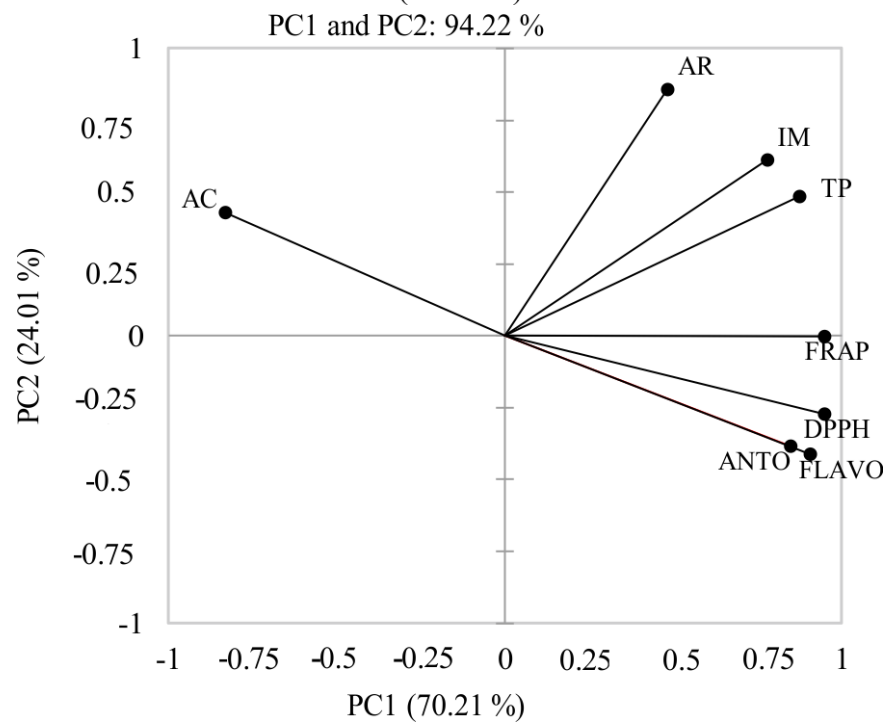

Descriptors: 572.1: grafted on to 'IAC 572' unilateral cordon; 572.2: grafted on to 'IAC 572 ' unilateral cordon; 766.1: grafted on to 'IAC 766' unilateral cordon; 766.2: grafted on to 'IAC 766' unilateral cordon; AC: Acidity; AR: reducing sugars; IM: fruit-ripeness index TP: total phenolic compounds; FLAVO: total flavonoids; ANTO: anthocyanins; FRAP e DPPH: antioxidant capacity.

Figure 2. Principal Component Analysis of 'Niagara Rosada' grapes grafted on to different rootstocks and training systems over two productive cycles (2015 and 2016).

\section{Conclusion}

The 'IAC 766' rootstock trained to bilateral cordon positively impacted on the chemical quality of 'Niagara Rosada' grapes, especially anthocyanin content. This management practice should be selected to produce 'Niagara Rosada' grapes with good coloured fruits and high antioxidant properties, wherefore these quality traits are highly considered for the final product.

\section{Compliance with Ethical Standards}

Author contributions: Conceptualization: APJ, MAT; Data curation: APJ, CVB, MAT; Formal analysis: APJ, CVB, MAT; Funding acquisition: GPPL, MAT; Investigation: APJ, FJDN, GCM; Methodology: APJ, GPPL, MAT; Project administration: APJ; Resources: GPPL, MAT; Supervision: GPPL, MAT; Validation: APJ, FJDN, GCM, CVB; Writing - original draft: APJ, FJDN, GCM, CVB; Writing - review \& editing: GPPL, MAT.

Conflict of interest: The authors declared that there is no possible conflict of interest (professional or financial) that may influence the article.

Financing source: Coordenação de Aperfeiçoamento de Pessoal de Nível Superior - Brazil (CAPES) - Finance Code 001.

\section{Literature Cited}

Benzie, I. F.; Strain, J. J. The ferric reducing ability of plasma (FRAP) as a measure of "antioxidant power". Analytical biochemistry, v. 239, n. 1, p. 70-76, 1996. https://doi.org/10.1006/abio.1996.0292.

Borges, R. de S.; Silva, G.A.; Roberto, S.R.; Assis, A.M de; Yamamoto, L.Y. Phenolic compounds, favorable oxi-redox activity and juice color of "Concord" grapevine clones. Scientia Horticulturae, v. 161, p. 188-192, 2013. https://doi.org/10.1016/j.scienta.2013.07.011.

Carvalho, C. de; Kist, B. B.; Beling, R. R. Anuário brasileiro de horti\&fruti 2020. Santa Cruz do Sul: Editora Gazeta, 2020. 94p. https://www.editoragazeta.com.br/sitewp/wp-content/ uploads/2020/05/HORTIFRUTI_2020.pdf. 29 Mar. 2021.

Colombo, F.; Di Lorenzo, C.; Regazzoni, L.; Fumagalli, M.; Sangiovanni, E.; Sousa, L.P. de; Bavaresco, L.; Tomasi, D.; Bosso, A.; Aldini, G.; Restani, P.; Dell'Agli, M. Phenolic profiles and anti-inflammatory activities of sixteen table grape (Vitis vinifera L.) varieties. Food \& Function, v. 10, n. 4, p. 1797-1807, 2019. https://doi. org/10.1039/C8FO02175A.

Ferreira, D. F. Sisvar: Um sistema computacional de análise estatística. Ciencia e Agrotecnologia, v. 35, n. 6, p. 1039-1042, 2011. https:// doi.org/10.1590/S1413-70542011000600001.

Gutiérrez-Gamboa, G.; Carrasco-Quiroz, M.; Verdugo-Vásquez, N.; Díaz-Gálvez, I.; Garde-Cerdán, T.; Moreno-Simunovic, I. Characterization of grape phenolic compounds of "Carignan" grapevines grafted on to "País" rootstock from Maule Valley (Chile): implications of climate and soil conditions. Chilean Journal of Agricultural Research, v. 78, n. 2, p. 310-315, 2018. https://doi.org/10.4067/S0718-58392018000200310.

Kim, Y. K.; Guo, Q.; Packer, L. Free radical scavenging activity of red ginseng aqueous extracts. Toxicology, v. 172, n.2, p. 149-156, 2002. https://doi.org/10.1016/S0300-483X(01)00585-6. 
Lee, J.; Wrolstad, R. W. D.; Ronald, E. Determination of total monomeric anthocyanin pigment content of fruit juices, beverages, natural colorants, and wines by the $\mathrm{pH}$ differential method: collaborative study. Journal of AOAC International, v. 88, n. 5, p. 1269-1278, 2005. https://doi.org/10.1093/jaoac/88.5.1269.

Liu, Y.; Yan, J.; Li, Q.; Wang, J.; Shi, Y. Effect of training systems on accumulation of flavan-3-ols in Cabernet Sauvignon grape seeds at the north foot of Mt. Tianshan. South African Journal of Enology and Viticulture, v. 39, n. 1, p. 35-46, 2018. https://doi. org/10.21548/39-1-1579.

Mota, R. V. da; Souza, C.R. de; Favero, A.C.; Silva, C.P.C. e; Carmo, E.L. do; Fonseca, A.R.; Regina, M. de A. Produtividade e composição físico-química de bagas de cultivares de uva em distintos portaenxertos. Pequisa Agropecuária Brasileira, v. 44, n. 6, p. 576-582, 2009. https://doi.org/10.1590/S0100-204X2009000600005.

Nelson, N. A. A photometric adaptation of Somogyi method for the determination of glucose. Journal of Biological Chemistry, v. 153 , n. 2, p. 375-380, 1944. https://doi.org/10.1016/S00219258(18)71980-7.

Ozden, M.; Vardin, H.; Simsek, M.; Karaaslan, M. Effects of rootstocks and irrigation levels on grape quality of Vitis vinifera $\mathrm{L}$. cV. Shiraz. African Journal of Biotechnology, v. 9, n. 25, p. 3801-3807, 2010. https:// www.ajol.info/index.php/ajb/article/view/82499. 09 Apr. 2021.

Pimentel Júnior, A. Caracterização agronômica, fisiológica e bioquímica da videira 'Niagara Rosada' em diferentes sistemas de condução. Botucatu: Unesp, 2020. PhD Thesis. https:// repositorio.unesp.br/handle/11449/204180. 13 May. 2021.

Popova, M.; Bankova, V.; Butovska, D.; Petkov, V.; Nikolova-Damyanova, B.; Sabatini, A.G.; Marcazzan, G.L.; Bogdanov, S. Validated methods for the quantification of biologically active constituents of poplartype propolis. Phytochemical Analysis: An International Journal of Plant Chemical and Biochemical Techniques, v. 15, n. 4, p. 235240, 2004. https://doi.org/10.1002/pca.777.
Raij, B. V.; Cantarella, H.; Quaggio, J. A.; Furlani, A. M. C. (Ed.). Recomendações de adubação e calagem para o Estado de São Paulo. Campinas: IAC, 1997. 285p. (IAC. Boletim Técnico, 100).

Sabbatini, P.; Wierba, K.; Clearwater, L.; Howell, G.S. Impact of training system and pruning severity on yield, fruit composition, and vegetative growth of 'Niagara' Grapevines in Michigan. International Journal of Fruit Science, v. 15, n. 3, p. 237-250, 2015. https://doi.org/10.1080/15538362.201 5.1009971.

Silva, M. J. R. da; Padilha, C.V. da S.; Lima, M. dos S.; Pereira, G.E.; Venturini Filho, W.G.; Moura, M.F.; Tecchio, M.A. Grape juices produced from new hybrid varieties grown on Brazilian rootstocks - Bioactive compounds, organic acids and antioxidant capacity. Food Chemistry, v. 289, p. 714-722, 2019. https://doi.org/10.1016/j.foodchem.2019.03.060.

Silva, M. J. R. da S.; Vedoato, B.T.F.; Lima, G.P.P.; Moura, M.F.; Coser, G.M. de A.G.; Watanabe, C.Y.; Tecchio, M.A. Phenolic compounds and antioxidant activity of red and white grapes on different rootstocks. African Journal of Biotechnology, v. 16, n. 13 , p. $664-671$, 2017. https://doi.org/10.5897/ AJB2016.15837.

Singleton, V. L.; Rossi Jr, J. A. Colorimetry of total phenolics with phosphomolybidic-phosphotungstic acid reagents. American Journal of Enology and Viticulticulture, v. 16, p. 144-158, 1965. https://www.ajevonline.org/content/16/3/144. 09 Apr. 2021.

Tecchio, M. A.; Moura, M.F.; Teixeira, L.A.J.; Pires, E.J.P.; Leonel, $S$. Influence of rootstocks and pruning times on yield and on nutrient content and extraction in "Niagara Rosada" grapevine. Pesquisa Agropecuária Brasileira, v. 49, n. 5, p. 340-348, 2014. https://doi.org/10.1590/S0100-204X2014000500003. 